\title{
Studi Pengaruh Model Pembelajaran Berbasis Proyek (Project Based Learning) Terhadap Kreativitas Mahasiswa Program Studi Pgsd Pada Mata Kuliah Konsep Dasar Ipa
}

\author{
Hairunisa $^{1, *}$, Arif Rahman Hakim ${ }^{1}$, Nurjumiati ${ }^{1}$ \\ ${ }^{1}$ STKIP Taman Siswa Bima \\ "anis010286@gmail.com
}

Artikel Info

Tanggal Publikasi

2019-12-30

Kata Kunci

Model PjBL

Kreativitas

Konsep Dasar IPA

\section{Abstrak}

Tujuan dari penelitian ini adalah untuk meningkatkan kreativitas mahasiswa Program Studi Sekolah Dasar (PGSD) melalui penerapan model pembelajaran project based learning pada matakuliah Konsep Dasar IPA. Penelitian ini dilaksanakan dengan desain One-Shot Case Study dengan subjek penelitian 48 mahasiswa program studi pendidikan guru sekolah dasar STKIP Taman Siswa Bima yang sedang mengampu matakuliah Konsep Dasar IPA. Data penelitian diperoleh dari analisis lembar observasi produk dengan skala berpikir kreatif (Creatif Thinking Scale/CTS). Analisis data penelitian dilakukan dengan teknik persentase dan diolah secara deskriptif. Hasil penelitian menunjukkan bahwa kreativitas mahasiswa dalam menghasilkan produk berupa alat peraga IPA sangat tinggi yaitu dengan nilai rata-rata 84 . Berdasarkan hasil tersebut, dapat disimpulkan bahwa penerapan model pembelajaran berbasis proyek (project based learning) dapat meningkatkan kreativitas mahasiswa Program Studi PGSD pada matakuliah Konsep Dasar IPA.

\section{PENDAHULUAN}

Konsep Dasar IPA merupakan salah satu matakuliah yang menghubungkan antara teori dan aplikasi yang memerlukan keterampilan berpikir kritis, kreativitas tinggi dan pemahaman konsep IPA yang baik dalam menghasilkan karya kontekstual secara individual maupun kelompok yang menjadi tujuan akhir dari matakuliah tersebut. Karya kontekstual yang dihasilkan nantinya akan dievaluasi melalui penilaian kompetensi keterampilan dengan menggunakan tes praktek maupun proyek. Dalam menghasilkan suatu karya, mahasiswa dituntut untuk berpikir kreatif terhadap produk yang didesain. Berpikir kreatif diartikan sebagai suatu kegiatan mental yang digunakan seseorang untuk membangun ide atau gagasan baru (Anggraeni, 2016). Hal ini sejalan menurut Rahayu (2011) bahwa berpikir kreatif melibatkan logika dan intuisi secara bersama-sama. Secara khusus dapat dikatakan berpikir kreatif sebagai satu kesatuan atau kombinasi dari berpikir logis dan berpikir divergen guna menghasilkan sesuatu yang baru. Sesuatu yang baru tersebut merupakan salah satu indikasi berpikir kreatif dalam IPA, sedangkan indikasi yang lain berkaitan dengan berpikir logis dan berpikir divergen.

Untuk menghasilkan suatu cara atau sesuatu yang baru dalam menghadapi suatu masalah atau situasi, maka diperlukan suatu kreativitas yang meruapakan suatu produk dari kemampuan berpikir kreatif. Kreativitas merupakan kemampuan mengimajinasikan, menafsirkan dan mengemukakan gagasan serta usaha yang memiliki daya cipta untuk kombinasi baru dari unsur sebelumnya yang sudah ada sehingga diperoleh peningkatan kualitas siswa dalam pengembangan dirinya (Rahayu, 2011). Kreativitas dan berpikir kreatif merupakan dua hal yang tidak dapat dipisahkan dalam menghasilkan suatu produk. Di era pendidikan 4.0, mahasiswa seharusnya dituntut untuk memiliki kreativitas yang tinggi melalui penerapan model-model pembelajaran agar memiliki bekal keterampilan (soft skill) ketika terjun di dunia kerja setelah lulus dari perguruan tinggi. 
Namun, hasil temuan di lapangan menyatakan bahwa kegiatan pembelajaran pada beberapa matakuliah di Prodi Pendidikan Guru Sekolah Dasar termasuk Konsep Dasar IPA umumnya masih berpusat pada dosen, dosen hanya menggunakan metode ceramah, tanya jawab, diskusi, memberikan tugas latihan dalam proses pembelajaran, mahasiswa kurang dilibatkan dalam proses pembelajaran IPA sehingga kemampuan berpikir kreatif mahasiswa kurang terasah dan aspek keterampilan dan sikap juga banyak terabaikan. Dampak dari permasalahan tersebut adalah kreativitas mahasiswa belum mengalami peningkatan yang cukup signifikan dari tahun ke tahun. Untuk mengatasi permasalahan tersebut, maka perlu dicarikan pendekatan pembelajaran yang tepat yang dapat mengembangkan keterampilan, kreativitas dan juga mampu meningkatkan penguasaan konsep (kognitif) pada matakuliah Konsep dasar IPA agar mengalami peningkatan. Salah satunya adalah melalui penerapan model pembelajaran berbasis proyek atau Project Based Learning $(\mathrm{PjBL})$.

Model pembelajaran Project Based Learning (PjBL) merupakan proses pembelajaran yang secara langsung melibatkan siswa untuk menghasilkan suatu proyek. Pada dasarnya model pembelajaran ini lebih mengembangkan keterampilan memecahkan masalah dalam mengerjakan sebuah proyek yang dapat menghasilkan sesuatu. Dalam implementasinya, model ini memberikan peluang yang luas kepada siswa untuk membuat keputusan dalam memilih topik, melakukan penelitian, dan menyelesaikan sebuah proyek tertentu. Pembelajaran dengan menggunakan proyek sebagai metoda pembelajaran dimana para siswa bekerja secara nyata, seolah-olah ada di dunia nyata yang dapat menghasilkan produk secara realistis (Baharudin, 2009). Adapun beberapa kelebihan PjBL, antara lain (Lindawati, 2013): (1) Menyiapkan mahasiswa pada lapangan pekerjaan, melalui pengembangan keterampilan dan kemampuan seluas-luasnya, (2) Meningkatkan motivasi mahasiswa dalam mengembangkan pengetahuan dan ketrampilannya ketika mereka menyelesaikan tugas proyek, (3) Meningkatkan kolaborasi untuk mengkonstruksi pengetahuan, (4) Meningkatkan hubungan sosial dan keahlian berkomunikasi, kerja kelompok dalam proyek sangat diperlukan mahasiswa dalam mengembangkan dan mempraktikkan keterampilan komunikasi. (5) Meningkatkan percaya diri mahasiswa sehingga mahasiswa merasa bangga akan memenuhi sesuatu yang mempunyai nilai di luar kelas pembelajaran, (6) Memberi kesempatan pada mahasiswa untuk mengembangkan kemampuan belajar secara individu dengan berbagai pendekatan belajar.

Berdasarkan hasil penelitian yang telah dilakukan oleh Sari pada tahun 2018 terkait penerapan model pembelajaran $\mathrm{PjBL}$ sebagai upaya dalam meningkatkan kreativitas mahasiswa, menyatakan bahwa penerapan model pembelajaran Project Based Learning (PjBL) dapat meningkatkan kreativitas mahasiswa. Dari hasil penelitian tersebut, dapat dijadikan referensi dengan harapan bahwa dengan diterapkannya model pembelajaran Project Based Learning ( $\mathrm{PjBL}$ ) ini diharapkan mampu meningkatkan kreativitas mahasiswa dalam menghasilkan produk (karya) pada matakuliah Konsep Dasar IPA sehingga mahasiswa mampu mengembangkan keterampilan dan kemampuan yang dimilikinya dengan seluas-luasnya baik dalam proses pembelajaran maupun dalam kehidupan sehari-hari.

\section{METODE PENELITIAN}

Penelitian ini dirancang menggunakan desain One-Shot Case Study. Subjek penelitian dalam penelitian ini adalah mahasiswa Program Studi Pendidikan Guru Sekolah Dasar (PGSD) yang mengampu matakuliah Konsep Dasar IPA yang berjumlah 48 mahasiswa. Pada penelitian ini proses pembelajarannya lebih menekankan pada pembelajaran berbasis proyek untuk membuat alat peraga dari sampah yang tidak dipakai yang ada di sekitar lingkungan. Hasil karya mahasiswa diobservasi sebagai hasil kemampuan berpikir kreatif dalam mengolah sampah menjadi media atau bahan ajar seperti alat peraga. Instrumen yang dugunakan dalam penelitian ini berupa lembar observasi produk. Data yang diobservasi berupa skala berpikir kreatif (Creative Thinking Scale / CTS) sebagai penilaian proses desain kreatif dari sebuah proyek. Data yang diperoleh dianalisis dengan menggunakan rumus persentase yang dikemukakan oleh Sari (2018).

Keterangan :

$$
N a=\frac{X}{X m}
$$




$\begin{array}{ll}\mathrm{Na} & =\text { Nilai afektif } \\ \mathrm{X} & =\text { Skor yang diperoleh } \\ \mathrm{Xm} & =\text { Skor maximum }\end{array}$

Kriteria penilaian kreativitas diadopsi dan dimodifikasi dari Sari (2018) seperti Tabel 1 berikut ini.

Tabel 1. Kriteria Kreativitas Mahasiswa

\begin{tabular}{cc}
\hline$(\%)$ & Kriteria Kreativitas \\
\hline $81-100$ & Sangat Tinggi \\
$61-80$ & Tinggi \\
$41-60$ & Sedang \\
$21-40$ & Rendah \\
$1-20$ & Sangat rendah \\
\hline
\end{tabular}

\section{HASIL DAN PEMBAHASAN}

Berdasarkan hasil penelitian yang telah dilakukan, kreativitas mahasiswa dalam mengolah barang yang tidak dipakai (sampah) menjadi alat peraga melalui pembelajaran Project Based Learning menunjukkan produk-produk alat peraga yang diharapkan. Produk-produk ini dinilai dengan menggunakan skala berpikir kreatif (Creative Thinking Scale / CTS). Berikut nilai rata-rata kreativitas mahasiswa dalam mengolah sampah menjadi produk alat peraga, seperti yang ditunjukkan pada Tabel 2 berikut ini.

Tabel 2. Nilai rata-rata kreativitas mahasiswa pada matakuliah Konsep Dasar IPA dalam menghasilkan produk

\begin{tabular}{cccc}
\hline No & Aspek yang diamati & Skor rata-rata & Kategori \\
\hline 1 & Perencanaan & 85,5 & Sangat Tinggi \\
2 & Pelaksanaan & 86 & Sangat Tinggi \\
3 & Laporan & 80,5 & Tinggi \\
\hline Rata-rata persentase kreativitas mahasiswa & 84 & Sangat Tinggi \\
\hline
\end{tabular}

Berdasarkan tabel 2 di atas, maka dapat diketahui bahwa nilai rata-rata kreativitas mahasiswa melalui pembelajatan $\mathrm{PjBL}$ berada pada kategori sangat tinggi dengan nilai rata-rata 84. Pada aspek perencanaan diperoleh nilai rata-rata 85,5 dengan kategori sangat tinggi dimana indikator penilaian pada aspek perencanaan adalah persiapan alat dan bahan serta gambar kerja. Sedangkan pada aspek pelaksanaan diperoleh nilai rata-rata 86 dengan kategori sangat tinggi, dimana indikator penilaian aspek pelaksanaan adalah sikap kerja, penggunaan alat, bahan, pengerjaan, perakitan dan finishing. Sementara itu, aspek laporan memiliki nilai rata-rata 80,5 dengan kategori tinggi. Indikator penilaian pada aspek laporan adalah performa dan kesesuaian produk yang dihasilkan. Dari hasil nilai rata-rata dengan menggunakan skala berpikir kreatif menyatakan bahwa mahasiswa memiliki kreativitas yang sangat tinggi. Hal ini mengindikasikan bahwa penerapan model pembelajaran berbasis proyek $(\mathrm{PjBL})$ dapat meningkatkan kreativitas mahasiswa. Dengan diterapkannya model pembelajaran PjBL, membuat kreativitas mahasiswa dalam mengolah sampah (barang tidak pakai) menjadi lebih terarah dan jelas.

Berdasarkan hasil penelitian di atas, melalui model pembelajaran PjBL mahasiswa dapat meningkatkan kreativitas dalam berkarya. Produk yang dihasilkan sangatlah memiliki nilai ekonomi yang tinggi sehingga memberi peluang bagi mahasiswa dalam menciptakan jiwa interpreneur (wirausaha). Dengan kata lain, model pembelajaran $\mathrm{PjBL}$ adalah model pembelajaran yang membutuhkan keterampilan dengan menggunakan prinsip belajar sambil mengerjakan (learning by 
doing). Hal ini sejalan menurut Nugraha (2018) menyatakan bahwa PjBL memberikan kesempatan pembelajar untuk meneliti, merencanakan, mendesain dan refleksi terhadap pembuatan proyek teknologi. Selain itu Rati (2017) mengemukakan bahwa model PjBL dapat meningkatkan kreativitas belajar siswa SMK 2 Blora. Berpikir kreatif dalam suatu PjBL tidak hanya membutuhkan perubahan metode mengajar dan suasana pembelajaran, tetapi juga harus mengadopsi metode asessmen baru seperti portofolio yang berdasarkan aktivitas mahasiswa. Portofolio akan merefleksikan apa yang sudah dipelajari oleh mahasiswa bagaimana cara mengajukan pertanyaan, menganalisis, mensitesis, mengatasi masalah dengan cara membuat ide baru, dan kemudian mendesain dan membuat suatu produk inovatif yang baru. Portofolio juga menampilkan bagaimana mahasiswa berinteraksi secara intelektual, emosional dan social dengan rekan kerjanya.

\section{KESIMPULAN}

Berdasarkan hasil penelitian yang diperoleh, maka dapat disimpulkan bahwa model pembelajaran Project Based Learning (PjBL) dapat meningkatkan kreativitas mahasiswa program studi PGSD STKIP Taman Siswa Bima pada matakuliah Konsep Dasar IPA. Kreativitas mahasiswa dalam mengolah sampah menjadi alat peraga pada matakuliah Konsep Dasar IPA sangat tinggi dengan nilai rata-rata 84 .

\section{Daftar Pustaka}

Anggraeni, D. (2016). Meningkatkan Kreativitas Siswa dengan Menggunakan Model Project Based Learning pada Mata Pelajaran IPA Materi Pernapasan Manusia. Jurnal KALAM CENDEKIA. Vol. 4 (1) : 19 $-25$

Baharuddin, R, W. (2009). Project Based Learning (PjBL) Practice at Politeknik Kota Bharu Malaysia. Journal International Education Studies, Vol. 2 (4) : 140-148.

Lindawati. 2013. Penerapan Model Pembelajaran Project Based Learning untuk Meningkatkan Kreativitas Siswa MAN 1 Kebumen. Radiasi. Vol. 3 (1) : 42-45.

Nugraha, A. R., dkk. 2018. Penerapan Model Pembelajaran Project Based Learning (PjBL) untuk Meningkatkan Kreativitas dan Hasil belajar IPA Siswa Kelas V SD. Jurnal KALAM CENDEKIA. Vol. $6(4): 9-15$

Rahayu. (2011). Pembelajaran Sains dengan Pendekatan Keterampilan Proses untuk Meningkatkan Hasil Belajar dan Kemampuan Berpikir Kreatif Siswa. Jurnal Pendidikan Fisika Indonesia. Vol 7 (1) : 106-110.

Rati, N. W. 2017. Model Pembelajaran Berbasis Proyek, Kreativitas dan Hasil Belajar Mahasiswa. Jurnal Pendidikan Indonesia. Vol 6 (1): 60 - 71

Sari, R. T. (2018). Penerapan Model Pembelajaran Project Based Learning (PjBL) dalam Upaya Peningkatan Kreativitas Mahasiswa. Varia Pendidikan Kajian Penelitian Pendidikan. Vol 30, (1) : 79-83 